UNITED STATES DEPARTMENT OF THE INTERIOR

Harold L. Ickes, Secretary

GEOLOGICAL SURVEY

W. C. Mendenhall, Director

Bulletin 899-B

GEOLOGIC STRUCTURE AND OCCURRENCE OF GAS IN PART OF SOUTHWESTERN NEW YORK

Part 2. SUbSURFACE STRUCTURE

IN PART OF SOUTHWESTERN NEW YORK AND MODE OF OCCURRENCE OF GAS

IN THE MEDINA GROUP

BY

G. B. RICHARDSON

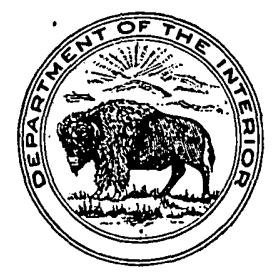

UNITED STATES

GOVERNMENT PRINTING OFFICE

WASHINGTON : 1941

For sule hy the Superintendent of Documents, Washington, D. C. - . - . - Price 30 cents 


\section{NOTE}

The Geological Survey in 1934, 1935, and 1936 studied the geologic structure and the occurrence of natural gas in the Oriskany and Medina sandstones in a large part of southwestern New York. The geologists have prepared separate reports on the areas for which they were responsible. However, as these areas are adjacent and form a real unit both geographically and geologically, the two reports are issued as parts of a single bulletin. No edition of the consolidated volume will be published, but the two parts may be bound together if desired.

II 


\section{CONTENTS}

Abstract $\ldots \ldots \ldots 6069$

Introduction $\ldots \ldots \ldots$



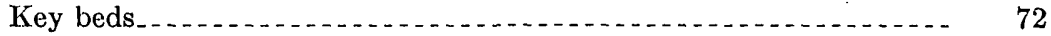

Convergence of strata.

Thickness of stratified rocks in the vicinity of Olean ............ 73



Gas in the Medina group........ 75

Relation of gas to structure

Relation of gas to lithology

Well records

\section{ILLUSTRATIONS}

Plate 5. Map of southwestern New York showing location of wells.......

6. Map showing isopach lines that represent intervals between the top of the Medina group and the top of the Onondaga limestone and between the top of the Onondaga limestone and the top of the Tully limestone

7. Map showing by contour lines drawn on the top of the Onondaga limestone the subsurface structure in part of southwestern New York, approximate outlines of principal gas-producing areas, and location of selected wells

8. Map showing structure contour lines drawn on the top of the Medina group and location of selected gas wells and dry holes in part of Erie County 



\title{
GEOLOGIC STRUCTURE AND OCCURRENCE OF GAS IN PART OF SOUTHWESTERN NEW YORK
}

\section{PART 2. SUBSURFACE STRUCTURE IN PART OF SOUTH- WESTERN NEW YORK AND MODE OF OCCURRENCE OF GAS IN THE MEDINA GROUP}

\author{
By G. B. RICHARDSON
}

\section{ABSTRACT}

Based on the records of several hundred deep wells, contour maps have been prepared showing the monoclinal structure of part of western New York, and isopach lines have been drawn showing the westward convergence of the rocks. The mode of occurrence of natural gas in the Medina group is briefly discussed. The location of the gas fields has not been determined by structural traps, but rather stratigraphy and lithology are the controlling factors in trapping the gas, which occurs in porous lenses and streaks of sandstone sealed within impermeable beds. This mode of occurrences of the Medina gas makes the search for new fields in western New York more hazardous than in most natural gas regions. As structure has not formed traps for the gas there is no surface guide to favorable sites for testing, and new fields are found by haphazard drilling. It would be helpful, however, when wells are sunk, to study the lithology of the gas-bearing zone by an examination of the drill cuttings and core samples of the sand and to have electrical logs made of the wells to obtain measurements of permeability and porosity. Such tests may indicate the direction of greatest porosity in which the sand is more likely to contain gas.

\section{INTRODUCTION}

The records of several hundred deep wells were obtained in 1934 in connection with an investigation by the Geological Survey to determine the geologic structure in the general region of the Oriskany gas fields of south-central New York. ${ }^{1}$ This investigation was financed with funds. provided by the Federal Emergency Administration of Public Works. The well records were supplemented in 1935 by logs of selected wells that had been sunk in search of gas in the Medina fields in the western part of the State. With this information as a basis the accompanying maps (pls. 5-8) have been prepared showing the subsurface structure in part of western New York, the convergence

\footnotetext{
I Bradley, W. H., and Pepper, J. F., Structure and gas possibilities of the Oriskany sandstone in Steuben, Yates, and parts of the adjacent counties, New York: U. S. Geol. Survey Bull. 899-A, pp. 1-68, 1938.
} 
of the strata, and the relation of the occurrence of natural gas to geologic structure in part of Erie County.

The logs of the wells were obtained from many sources. For courteously supplying records and other information the writer is under obligation to the following organizations and individuals:

Belmont Quadrangle Drilling Corporation, F. M. Brewster and J. A. Thompson; Godfrey L. Cabot, Inc., C. D. Whorton; Empire Gas \& Fuel Co., G. Holbrook and C. T. Major; Finance Oil \& Gas Co., Thomas Mills; Iroquois Gas Co., L. A. Brown and A. M. Nicholson; Keystone Gas Co., H. A. Wallace; Lycoming Producing Corporation, J. F. Robinson, U. F. Boyer, and F. H. Finn; New York State Museum and State Geological Survey, C. C. Adams, R. Ruedemann, D. H. Newland, and C. A. Hartnagel; New York State Oil Producers Association, N. Sullivan; North Penn Gas Co., J. Gaddess; Pavilion Natural Gas Co.; Penn-York Natural Gas Co., J. Reeves, H. E. Boyd, and N. C. Davies; Republic Light, Heat \& Power Co., S. B. Severson and G. M. Merrill; Rochester Gas \& Electric Co., A. M. Beebe and L. H. East; Solvay Process Co., R. H. Perkins and W. C. Phalen; Torrey, Fralich \& Simmons, C. E. Fralich, A. C. Simmons, and W. H. Young; University of Rochester, H. L. Alling; and G. H. Chadwick, of Catskill, F. L. Dougherty, of Dunkirk, H. H. Cranston, of Fredonia, and S. T. Lockwood, of Buffalo.

\section{STRATIGRAPHY}

The generalized stratigraphic sequence in central and western New York is shown in the accompanying section, after Newland and Hartnagel and Goldring, of the State Museum. ${ }^{2}$ The section shows the stratigraphic position of the principal gas-producing zones and of the key beds reported in the driller's logs of wells. The stratigraphic nomenclature used in the present report follows that given in the section and also follows current usage in the gas fields of western New York. The Medina group as thus used is assigned entirely to the Silurian. The strata here designated Oswego and Queenston in the lower part of the group have been correlated with formations elsewhere that are' assigned an Ordovician age in other reports of the Federal Geological Survey.

2 Newland, D. H., and Hartnagel, C. A., Review of the natural gas and petroleum developments in New York State: New York State Mus. Bull. 295, pp. 106-107, 1932. Goldring, Winifred, Handbook of paleon. tology for beginners and amateurs; Part 2, The formations: New York State Museum Handbook 10, pp. 190-191, 1931. 
Generalized geologic section in central and western New York

[Chiefly after D. H. Newland, C. A. Hartnagel, and Winifred Goldring]

\begin{tabular}{|c|c|c|c|}
\hline System or series & Group or formation & Description & $\underset{\text { (feet) }}{\text { Thickness }}$ \\
\hline \multirow[t]{2}{*}{ Pennsylranian. } & Olean. & $\begin{array}{l}\text { Coarse conglomerate with well-rounded peb- } \\
\text { bles mostly of vein quartz. Texture changes } \\
\text { rapidly both horizontally and vertically into } \\
\text { coarse white sandstone. }\end{array}$ & $60-70$ \\
\hline & Unconformity. & $\begin{array}{l}\text { Absence of Mauch Chunk and associated } \\
\text { formations. }\end{array}$ & \\
\hline \multirow{3}{*}{$\begin{array}{l}\text { Mississippian or Up- } \\
\text { per Devonian. }\end{array}$} & Knapp. & Conglomerate and interbedded shale. & $60-105$ \\
\hline & Oswayo. & $\begin{array}{l}\text { Fossiliferous olive-green and rust-colored } \\
\text { limonitic shales. Two-foot bed of very } \\
\text { fossiliferous limestone near base. Probably } \\
\text { small unconformity between Oswayo and } \\
\text { Cattaraugus. A few thin beds of sandstone. }\end{array}$ & $160-250$ \\
\hline & Cattaraugus. & $\begin{array}{l}\text { Bright-red shales with interbedded green or } \\
\text { bluish shales and fine-grained micaceous } \\
\text { sandstones. Local beds of conglomerate } \\
\text { characterize the formation. At base is Wolf } \\
\text { Creek conglomerate. Conglomerates of } \\
\text { Cattaraugus beds have flat or discoidal } \\
\text { pebbles, some of jasper, distinguishing them } \\
\text { from Olean. }\end{array}$ & $300-350$ \\
\hline \multirow{8}{*}{ Devonian. } & Chemung. & $\begin{array}{l}\text { Gray, olive, and bluish shales, some dark } \\
\text { purple or chocolate color. Many thin beds } \\
\text { of argillaceous sandstone. Lower half of } \\
\text { Chemung contains the oil-producing sands } \\
\text { of the State. }\end{array}$ & $1,200-1,500$ \\
\hline & Portage. & $\begin{array}{l}\text { Sandstone, flags, and black carbonaceous } \\
\text { shales. Has gas-bearing strata. }\end{array}$ & $1,200-1,400$ \\
\hline & Genesee. & Black shale. & $25-50$ \\
\hline & Tully. & Gray limestone. & $0-30$ \\
\hline & Hamilton. & $\begin{array}{l}\text { Blue, gray, and olive shales. Basal portion, } \\
\text { Marcellus black shale, which is gas-bearing. }\end{array}$ & $600-700$ \\
\hline & Onondaga. & $\begin{array}{l}\text { A heavy bedded limestone, the "flint" of the } \\
\text { drillers. Gas-bearing. }\end{array}$ & $60-130$ \\
\hline & Oriskany. & $\begin{array}{l}\text { Sandstone. Gas-bearing in Schuyler, Yates, } \\
\text { Steuben, and Allegany Counties. }\end{array}$ & $0-20$ \\
\hline & Uneonformity. & Absence of Helderbergian formations. & \\
\hline \multirow{4}{*}{ Silurian. } & Salina. & $\begin{array}{l}\text { A series of water limes, gypseous shales, beds } \\
\text { of anhydrite and gypsum, rock salt. Red } \\
\text { shales at base. Upper portion of series gas } \\
\text { bearing. }\end{array}$ & $700-800$ \\
\hline & Niagara. & $\begin{array}{l}\text { Heavy bedded dolomites, Lockport and } \\
\text { Guelph. Rochester shale at base is of } \\
\text { Clinton age but usually logged with Niagara. } \\
\text { Gas in Seneca and Ontario Counties. }\end{array}$ & 200 \\
\hline & Clinton. & Limestones, shales, with thin bed of hematite. & $30-150$ \\
\hline & Mediua. & $\begin{array}{l}\text { Upper } 150 \text { feet white and red sandstones } \\
\text { (Albion). Most prolific gas horizon in State. } \\
\text { Main mass red shale (Queenston); white } \\
\text { Oswego sandstone at base. }\end{array}$ & $1,100-1,200$ \\
\hline \multirow{3}{*}{ Ordovician. } & $\begin{array}{l}\text { I.orraine, or "Hudson } \\
\text { River," and Utica. }\end{array}$ & $\begin{array}{l}\text { A series of alternating beds of sandstones and } \\
\text { shales. At base is Utica black shale. }\end{array}$ & $500-600$ \\
\hline & 'Trenton. & $\begin{array}{l}\text { Alternating dark limestones and shales. Pro- } \\
\text { ductive in Onondaga, Oswego, Oneida, and } \\
\text { Lewis Counties. Many large gas pockets. }\end{array}$ & $700-900$ \\
\hline & $\begin{array}{l}\text { Tribes Hill and Little } \\
\text { Falls. }\end{array}$ & $\begin{array}{l}\text { Heavy bedded limestones. Also known as the } \\
\text { "Calciferous" formation. Basal beds in part } \\
\text { belong to the Cambrian, the boundary being } \\
\text { indefinite. }\end{array}$ & $100-140$ \\
\hline Cambrian. & Potsdam. & $\begin{array}{l}\text { A sandstone where present directly over- } \\
\text { lying the pre-Cambrian. Reported in a few } \\
\text { deep wells in western New York. Gas in } \\
\text { one or two wells in central New York. }\end{array}$ & $10-50$ \\
\hline Cambrian. & & $\begin{array}{l}\text { Reported in several wells in western and } \\
\text { central New York. }\end{array}$ & \\
\hline
\end{tabular}




\section{KEY BEDS}

The logs of wells as reported by the drillers in general show only a few readily recognizable or key beds. (See list of wells, pp. 79-91.). One of the most useful of these beds for determining the stratigraphy and structure is the Onondaga limestone, of Middle Devonian age, which is widely distributed and readily recognized by well drillers. It immediately underlies the black Marcellus shale and overlies the Oriskany sandstone where that is present. The Onondaga is a massive gray cherty linestone ranging from less than 50 to more than 150 feet in thickness and is reported as "flint" by the drillers. It crops out, commonly forming an escarpment, from Lake Erie in the vicinity of Buffalo to the Hudson. Valley in the vicinity of Albany and extends southward into Pennsylvania. In New York the Onondaga is a persistent limestone, though locally it is somewhat shaly in its upper part.

The Oriskany sandstone lying at the base of the Devonian system in western New York was deposited in irregular thickness in a sea transgressing the eroded surface of an old land mass. It locally disappears, yet it is apparently more continuous as a sheet deposit than the lenticular beds of sandstone that constitute some of the oil and gas reservoirs of Upper Devonian age. The type locality of the Oriskany is at Oriskany Falls, Oneida County, N. Y., where it is a light-gray fossiliferous coarse-grained quartz sandstone about 20 feet thick. The Oriskany sandstone is of economic importance because of the occurrence in it of large quantities of natural gas. The structure and gas possibilities of the Oriskany in a part of the State are discussed by Bradley and Pepper in part 1 of this bulletin. ${ }^{3}$ Numerous well records show the occurrence of the Oriskany sandstone in central New York. The approximate northwestern limit of its occurrence underground, as indicated by the records of wells drilled before 1936, is shown on plate 5.

Another important key bed is the Tully limestone, lying at the base of the Upper Devonian series, between the overlying Genesee black shale and dark shale in the uppermost part of the Hamilton group. It apparently does not underlie so large an area as the Onondaga limestone, but recent drilling shows that it has a greater extent than was formerly realized. The Tully limestone crops out in the Finger Lake region of central New York and extends into Pennsylvania, where its outcrop has recently been observed in the central part of the State. ${ }^{4}$ In New York the Tully is a massive gray limestone as much as 30 feet thick.

The key horizon that serves as a marker for the gas-bearing beds of Medina age (see p. 71) is designated by drillers as the "top of the

\footnotetext{
${ }^{3}$ Bradley, W. H., and Pepper, J. F., op. cit.

- Willard, Bradford, A Tully limestone outcrop in Pennsylvania: Pennsylvania Acad. Sci. Proc., vol. 8, pp. 57-62, 1934.
} 


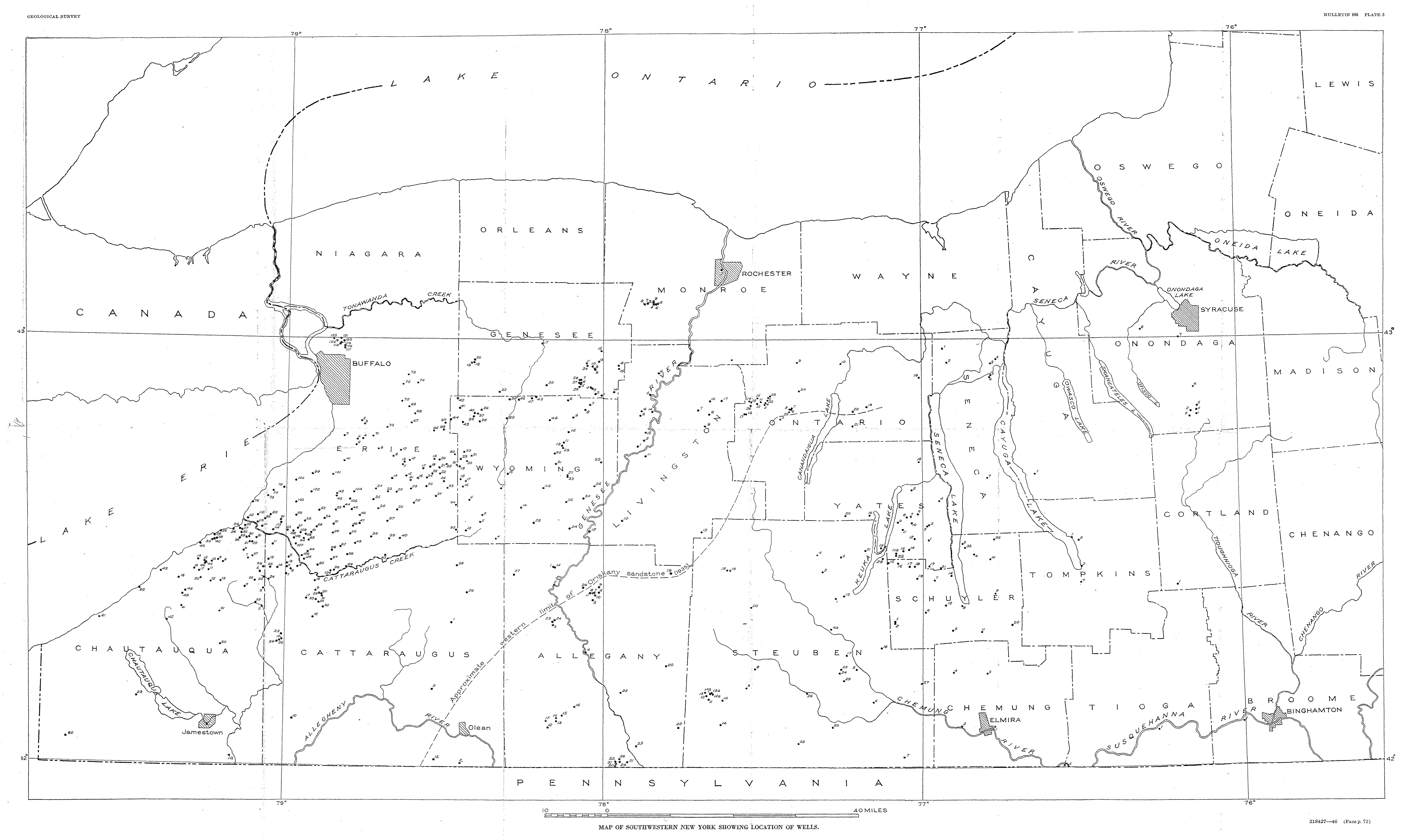




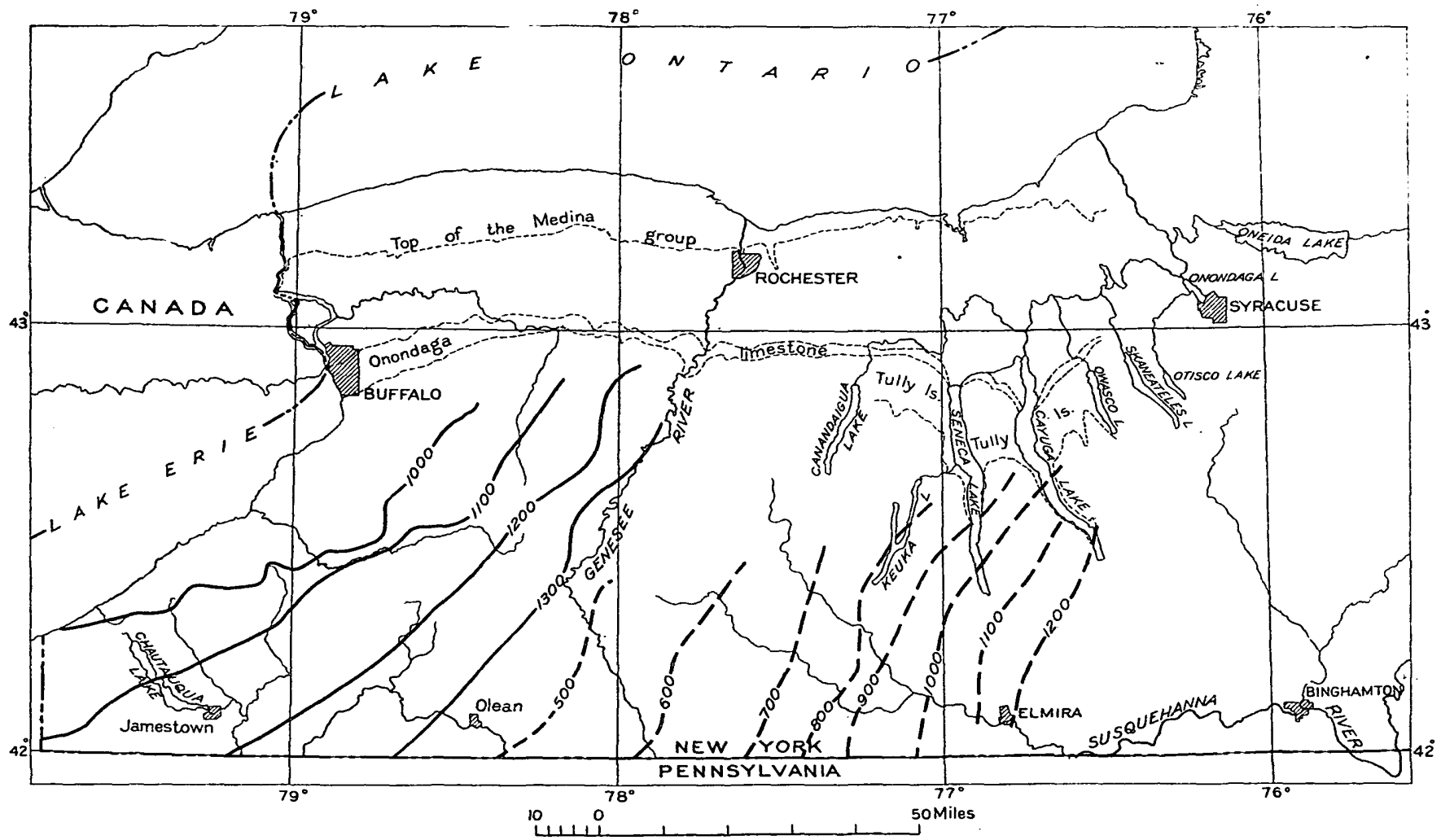

MAP SHOWING ISOPACH LINES THAT REPRESENT INTERVALS BETWEEN THE TOP OF THE MEDINA GROUP AND THE TOP OF THE ONONDAGA LIMESTONE (SHOWN BY SOLID LINES) AND BETWEEN THE TOP OF THE ONONDAGA LIMESTONE AND THE TOP OF THE TULLY LIMESTONE (SHOWN BY BROKEN LINES).

Location of outcrop of top of Medina group and outerop of Onondaga and Tully limestones from Geologic map of New York by New York State Museum. 
Red Medina." This marks the change from gray shale in the lower part of beds of Clinton age to an underlying bed of sandstone that despite the drillers' term "Red Medina," is not everywhere red. In places this sandstone beneath the Clinton is the so-called Gray band or Thorold sandstone, which averages only about 5 feet in thickness. The age of the Gray band, whether Clinton or Medina, is doubtful, though the New York State Museum ${ }^{5}$ now includes it in the Clinton. The Gray band seems to be locally absent where shale in the Clinton is reported to lie directly on red sandstone at the top of the Albion sandstone of the Medina group.

\section{CONVERGENCE OF STRATA}

Measurement of the stratigraphic intervals between the key beds reported in the records of the wells shows clearly the convergence of the strata. The rocks constitute a great wedge of sediments that decrease in thickness from east to west. The intervals between the top of the Medina group and the top of the Onondaga limestone and between the tops of the Onondaga and Tully limestones are shown by iropach lines on plate 6 .

The Onondaga-Tully interval decreases from 1,700 feet in the vicin$y$ of Owego, Tioga County, to 500 feet in the vicinity of Portville, Cattaraugus County, at the rate of about 13 feet per mile. The Onondaga-Medina interval decreases from 2,500 feet in the vicinity of Ludlowville, Tompkins County, to 1,400 feet in the vicinity of Livonia, Livingston County, at the rate of about 22 feet per mile, and from more than 1,500 feet in eastern Allegany County to less than 1,000 feet in western Erie County, at the rate of about 11 feet per mile. These isopach lines are based on scattered measurements and are necessarily generalized.

Relatively few measurements have been published showing the .convergence in the beds above the Tully limestone, but an indication of conditions is afforded by rough measurements at two places of the interval between the Onondaga limestone and the Dunkirk shale, a formation in the Upper Devonian series. Near Dunkirk, Chautauqua County, that interval as shown by well records is about 800 feet, and in the vicinity of Woodhull, Steuben County, where the Dunkirk shale has become the Dunkirk sandstone, the interval between the base of the Dunkirk and the Onondaga limestone in a deep well, Steuben County No. 22, is about 4,000 feet, indicating a convergence of about 3,200 feet in a distance of a little more than 100 miles.

\section{THICKNESS OF STRATIFIED ROCKS IN THE VICINITY OF OLEAN}

One of the results of the recent deep drilling has been to permit a closer estimate than heretofore has been possible of the thickness of the rocks between the Olean conglomerate member of the Pottsville

${ }^{3}$ Goldring, Winifred, op. cit., p. 321.

$218427-40-2$ 
formation, of Pennsylvanian age, and rocks of pre-Cambrian age. The well on the Quinlan farm located 5 miles south of Olean (Cattaraugus County well No. 2, p. 80), drilled in 1933, was started about 600 feet below the Olean conglomerate and reached the top of the Onondaga limestone at a depth of 4,188 feet. At this location the isopach lines show an interval of about 1,450 feet between the top of the Onondaga limestone and the top of the Medina group (pi. 6) and, assuming that the Medina-pre-Cambrian interval is at least as much as that at Rochester-2,847 feet-(Monroe County well No. 2 ), a thickness of about 9,085 feet between the Olean conglomerate and the pre-Cambrian rocks in the vicinity of Olean is indicated.

\section{STRUCTURE}

That part of New York State lying south of Lake Ontario and west of the escarpment of the Catskill Mountains is in the northern part of the Appalachian synclinorium. This trough lies between the Allegheny Front and the Cincinnati arch and at the northeast rises on the flank of the Adirondack dome. Northwestward from the Allegheny Front, which marks the western border of the zone of closely folded rocks of the Appalachian province, the folds decrease in steepness and gradually fade away in irregular wrinkles. Locally the rocks are faulted. Farther northwestward the beds form a monoclinal slope on the flank of the Cincinnati arch, and north of Lake Ontario the strata rise to the Laurentian Shield.

In western New York on the northwestern flank of the Appalachian synclinorium, where the structure is monoclinal, the well records (pp. 79-91) are sufficiently numerous for structure contours to be drawn on the top of the Onondaga limestone at intervals of 100 feet, as shown on plate 7 . These show that the strata dip east of south at an average rate of 40 to 50 feet to the mile. The Onondaga limestone along its outcrop in the western part of the State ranges in altitude from 600 to 800 feet above sea level, and the contours show the area in which the dip carries the limestone down to a depth of 700 feet below sea level. Records of a few wells show that farther south the Onondaga limestone lies as much as 1,700 feet below sea level in Chatauqua County and 3,400 feet below sea level in Broome County. These depths are due in part to folding and in part to the eastward thickening of the strata.

Structure contours drawn at intervals of 500 feet on the top of the Medina group and on the top of the Trenton limestone in central and western New York have recently been published by Hartnagel. ${ }^{6}$ In part of Erie County these Medina contours have been supplemented by the structure contours drawn at intervals of 50 feet on the top of the Medina group, as shown on plate 8. This map, which also shows

\footnotetext{
- Hartnagel, C. A., The Medina and the Trenton of western New York: Am. Assoc. Petroleum Genlo-
} gists Bull. 22, pp. 79-99, 1938. 
the location of selected gas wells and dry holes, is based on data courteously supplied by L. A. Brown and A. M. Nicholson, of the Iroquois Gas Co., and by other companies. In the area where these contours have been drawn the structure is distinctly monoclinal. In places there is some irregularity in the trend and spacing of the contours, but there is no suggestion of closure.

\section{GAS IN THE MEDINA GROUP}

Natural gas occurs in New York in rocks of the Devonian, Silurian, and Ordovician systems, but the principal source for many years has been the Albion sandstone of lower Silurian age, the uppermost formation of the Medina group. The Medina gas occurs in several fields, chiefly in Chautauqua, Cattaraugus, Erie, Genesee, and Wyoming Counties, in wells of small capacity but long life. The gas fields have been discussed in publications by Bishop, Newland, and Hartnagel. ${ }^{7}$

The present writer in 1935 obtained a few facts concerning the mode of occurrence of the Medina gas that are here summarized.

\section{RELATION OF GAS TO STRUCTURE}

The Medina gas fields of western New York are localized on a monocline (see plate 7 ). The structure of a relatively small area of the gas-bearing rocks in part of Erie County is shown in more detail on plate 8 , on which structure contours are drawn on the top of the Medina group at intervals of 50 feet. Selected gas wells and dry holes are also shown. It is evident from the maps, which do not indicate any closure, that structure has not determined the localization of the natural gas, although presumably the monocline was effective in facilitating the migration of gas up the rise of the strata until it became trapped.

The monoclinal structure of the rocks in the Medina gas fields is in marked contrast to the structure in the Oriskany gas fields in southcentral New York and northwestern Pennsylvania. In those fields the gas occurs on structural highs along the axes of anticlines, the structure serving as a trap for the gas. ${ }^{8}$ In the Medina gas fields, on the contrary, the gas traps are porous lenses or streaks sealed by nonpermeable parts of the reservoir rock (pp. 77-78).

\section{RELATION OF GAS TO LITHOLOGY}

The Medina group crops out in a belt about 10 miles wide south of Lake Ontario, and the Albion sandstone, at the top of the group, is well

\footnotetext{
7 Bishop, I. P., Report on petroleum and natural gas in western New York: New York State Geologist Ann. Rept. 17, pp. 9-63, 1899. Newland, D. H., The mineral resources of the State of New York: New York State Mus. Bulls. 223-224, pp. 165-197, 1921. Newland, D. H., and Hartnagel, C. A., Review of the natural gas and petroleum developments in New York State: New York State Mus. Bull. 295, pp. 101, 182, 1932: Recent natural gas developments in New York State: New York State Mus. Bull. 305, pp. 97-161, 1936. Harrnagel, C. A., The Medina and the Trenton of western New York: Am. Assoc. Petroleum Geologists Bull. 22, pp. 79-99, 1938.
}

B Bradley, W. H., and Pepper, J. F., op. cit. 
exposed in the gorge of the Niagara River. Dipping southward, in conformity with the regional structure, the Medina group extends underground far beyond the state boundary, and in southern Allegany County the gas sand lies more than 4,000 feet below sea level.

The Albion sandstone forms a sandy zone lying in the midst of a mass of shale. It is overlain by the Clinton formation and is underlain by the Queenston shale (see p. 71). The Albion sandstone consists of lenticular beds of red, gray, and white sandstone and interbedded red and gray shale somewhat more than 100 feet in thickness. The Whirlpool sandstone member, at the base of the formation, is the principal reservoir of natural gas. Although the Albion sandstone has been penetrated by many hundred drill holes put down in search of gas, very few detailed sections have been recorded. The following measurements are the most complete.

Section of Albion sandstone, Niagara Gorge ${ }^{9}$

\section{Clinton formation:}

Shale, gray.

Albion sandstone:

Sandstone, gray (Thordd Fant

Sandstone, red and gray, cross-bedded

Sandstone, red, thin-bedded, and shale......................... 20

Sandstone, gray, thick-bedded............ 4

Shale, reddish, and thin-bedded sandstone.

Saudstone, gray, thin-bedded ............. 5

Shale, blue-gray argillaceous or sandy . . .

Sandstone, white, cross-bedded (Whirlpool sandstone member) .......

Queenston shale:

Shale, red.

Section of Albion sandstone in a core drill hole at the Sterling salt mine, Cuylerville,

Clinton formation: Livingston County ${ }^{10}$

Shale, gray.

Albion sandstone:

Sandstone, gray

Sandstone and shale, gray, green, and red..........

Shale, red and green

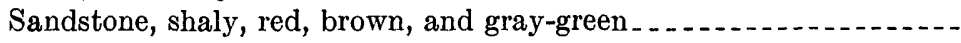

Shale, sandy, red, brown, and gray-green

Sandstone, white to brown

Shale, red, brown, and green

Sandstone, white to brownish

Not recorded.



Sandstone, coarse, brown ...

Queenston shale:

Shale, red:

- Kindle. E. M., and Taylor, F. B., U. S. Geol. Survey, Geol. Atlas, Niagara folio (No. 190), p. 6, 1913.

10 Courtesy of International Salt Co. 


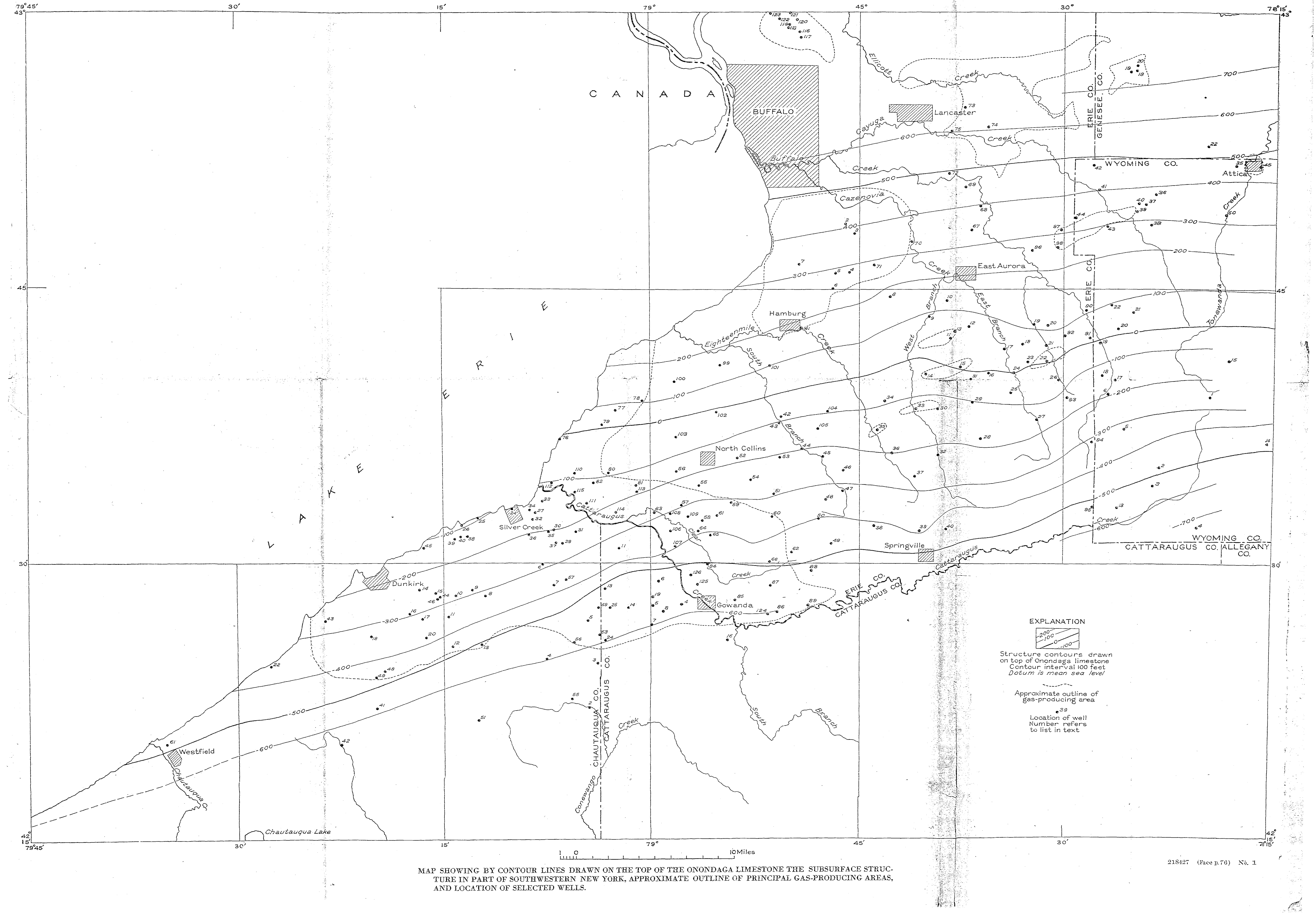




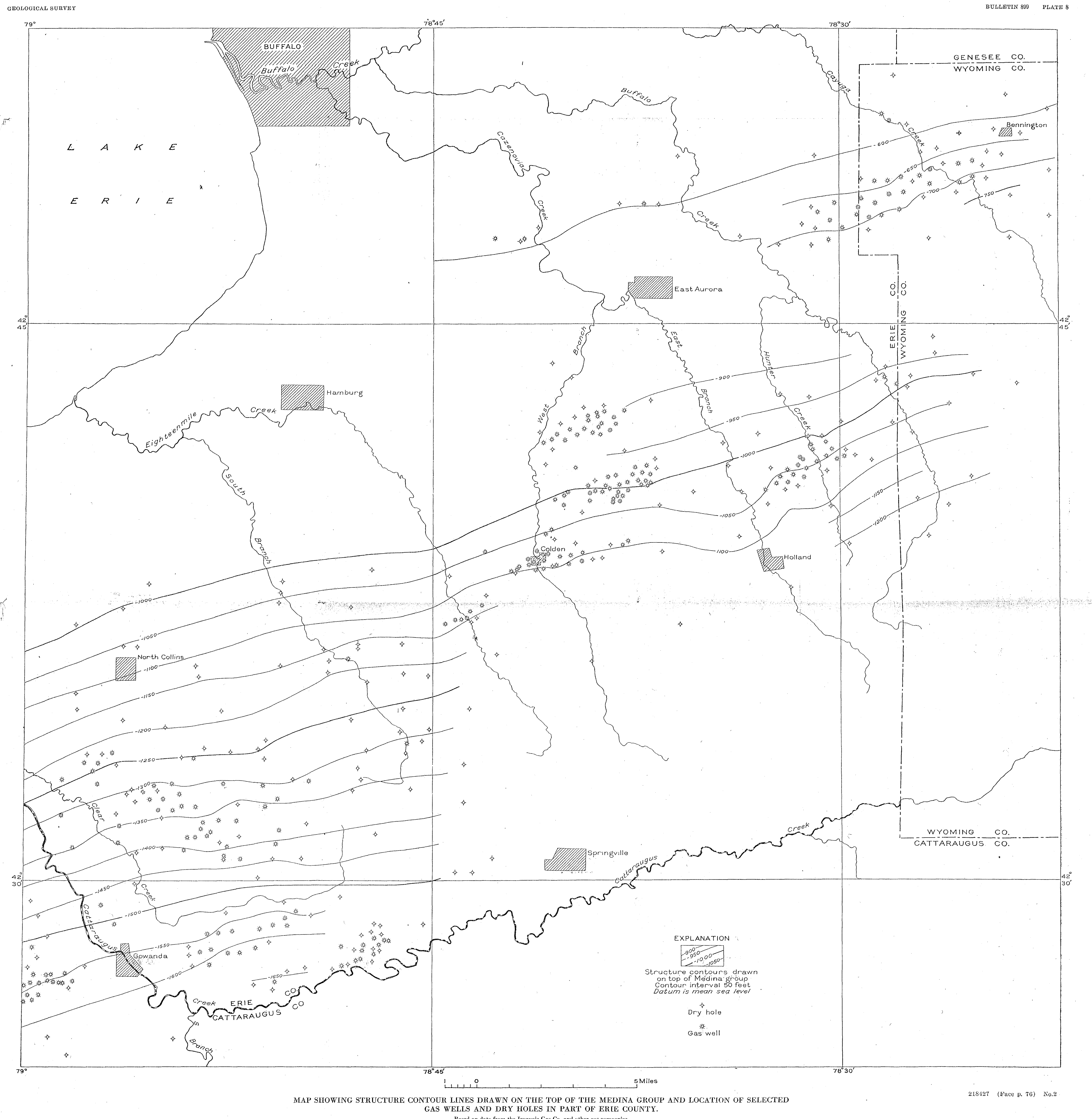


In the logs of wells as reported by drillers the Albion sandstone is subdivided into the White Medina sandstone (the Whirlpool sandstone member) at the base, the Red Medina sandstone and shale at the top, and an intervening shale "break." The following measurements selected at random from well drillers' records indicate the lenticularity and varying thicknesses of the subdivisions of the Albion sandstone in Erie County. The shale "break" and the White Medina locally disappear.

Measurements showing lenticularity of Albion sandstone in Erie County

[Thickness, in feet, as reported by well drillers]

\begin{tabular}{|c|c|c|c|c|c|c|c|c|c|c|c|c|c|c|c|c|c|c|c|c|c|}
\hline & $\mathbf{A}$ & B & C & D & $\mathbf{E}$ & $\mathbf{F}$ & $\mathrm{O}$ & $\mathrm{H}$ & I & $\mathbf{J}$ & $\mathbf{K}$ & L & $\mathbf{M}$ & $N$ & 0 & $\mathbf{P}$ & $Q$ & $\mathbf{R}$ & $\mathrm{S}$ & $\mathbf{T}$ & $\mathrm{U}$ \\
\hline $\begin{array}{l}\text { Albion sandstone: } \\
\text { Red Medina sandstone } \\
\text { nnd shale, at top..... } \\
\text { Shale "break"'-.... } \\
\text { White Medina sand- } \\
\text { stone, at base }\end{array}$ & $\begin{array}{l}80 \\
18\end{array}$ & $\begin{array}{c}84 \\
15 \\
12\end{array}$ & $\begin{array}{r}98 \\
0 \\
0\end{array}$ & $\begin{array}{l}80 \\
10 \\
20\end{array} \mid$ & $\begin{array}{r}120 \\
0 \\
0\end{array}$ & \begin{tabular}{|l|}
81 \\
14 \\
22
\end{tabular} & $\begin{array}{r}83 \\
9 \\
18\end{array}$ & $\begin{array}{r}90 \\
3 \\
13\end{array}$ & $\begin{array}{l}84 \\
12 \\
20\end{array}$ & $\begin{array}{l}85 \\
26 \\
21\end{array}$ & $\begin{array}{r}82 \\
7 \\
26\end{array}$ & $\begin{array}{r}65 \\
7 \\
32\end{array}$ & $\begin{array}{r}100 \\
0 \\
0\end{array}$ & $\begin{array}{r}85 \\
16 \\
8\end{array}$ & $\begin{array}{r}97 \\
0 \\
0\end{array}$ & $\begin{array}{l}85 \\
11 \\
20\end{array}$ & $\begin{array}{l}81 \\
14 \\
20\end{array}$ & $\begin{array}{l}81 \\
10 \\
20\end{array}$ & $\begin{array}{l}72 \\
10 \\
10\end{array}$ & $\left|\begin{array}{r}98 \\
2 \\
14\end{array}\right|$ & $\begin{array}{r}80 \\
0\end{array}$ \\
\hline
\end{tabular}

The White Medina, or Whirlpool, sandstone member of the Albion sandstone is indurated and fine-grained and is composed almost entirely of semirounded and subangular quartz grains of variable size, the maximum measured being less than 0.5 millimeter in diameter and the smallest less than 0.05 millimeter. A very subordinate amount of mica is present. The cement is chiefly secondary quartz, but locally it contains some calcite. The porosity and permeability of the sandstone are characteristically variable. The Albion sandstone as a whole, is generally reported to yield little or no water, but in places salt water is present in small quantity.

Natural gas occurs at various horizons in the Albion sandstone, chiefly in the White Medina but also in places in the overlying Red Medina. There is locally a tendency toward a linear distribution of the gas reservoirs somewhat north of east, possibly parallel to the old shore line of the sea in which the sand grains were distributed and sorted.

Gas occurs irregularly in parts of the sandstone that are sufficiently porous to serve as a reservoir and is absent where the sandstone is practically impermeable or "tight" as described by well drillers. The presence of gas is characteristically erratic, dry holes being surrounded by gas wells and vice versa. The irregular distribution of the gas is shown also by new wells in which the gas is under relatively high pressure, adjacent to old wells in which the pressure has been much reduced. The gas-bearing rocks are not continuously permeable beds; if they were the gas would migrate up the slope of the monocline and escape along the outcrop. The reservoirs are in effect lenses and irregular streaks of porous sandstone enclosed by impermeable rock. Lenses of sandstone are traps for gas in places where the sandstone 
merges into shale. Traps for gas in beds of the Albion sandstone are caused also by the deposition of secondary quartz upon the original quartz grains so as to enclose porous lenses within the cemented, impermeable rock. Moreover, the distribution and relative abundance of the coarser and finer grains of which the sandstone is composed have locally formed traps. This is shown by the physical tests of samples of the White Medina sandstone tabulated below.

Two samples of the White Medina sandstone, shot from wells in Erie County, were tested by P. G. Nutting, of the United States Geological Survey with the results here shown. Sample A represents an unproductive sand in a dry hole and Sample $B$ represents the pay streak in a commercial gas well. The differences in porosity and sand-grain distribution are striking. Fine grains, less than 0.052 millimeter in diameter, constitute more than 15 percent of the barren sand whose low porosity, less than 2 percent, is due to the abundance of the finest material, which is enough to prevent the occurrence of considerable voids in the rock; on the other hand the fines in the sample that represents a reservoir of natural gas are so few that voids remain unfilled and the porosity is more than 10 percent.

Physical tests of two samples of the Whirlpool sandstone member. (White Medina) of the Albion sandstone shot from wells in Erie County

\begin{tabular}{|c|c|c|c|}
\hline \multicolumn{2}{|c|}{ Grain-size distribution } & \multicolumn{2}{|c|}{ Percent } \\
\hline Mesh & $\begin{array}{c}\text { Size } \\
\text { (millimeters) }\end{array}$ & $\begin{array}{c}0+14 \\
\mathrm{~A}\end{array}$ & $\begin{array}{c}\text { gaswee } \\
B\end{array}$ \\
\hline Finer than 270. & Less than 0.052 & 15.59 & 7.98 \\
\hline $270-200$ & $0.052-0.074 \ldots$ & 3.38 & 4.73 \\
\hline $200-150 \ldots \ldots$ & $0.074-0.104 \ldots$ & 7. 18 & $M 22.95$ \\
\hline $150-100 \ldots \ldots$ & $0.104-0.147 \ldots$ & 12.05 & 22.82 \\
\hline $100-65 \ldots$ & $0.147-0.208 \ldots$ & 437.35 & 19. 19 \\
\hline $65-48 \ldots \ldots$ & $0.208-0.295 \ldots$ & 20.15 & 9.43 \\
\hline $48-35 \ldots \ldots . .$. & $0.295-0.417, \ldots \ldots \ldots \ldots$ & 4.30 & 8.62 \\
\hline On $35 \ldots \ldots$ & More than $0.417 \ldots \ldots$ & & 4. 26 \\
\hline
\end{tabular}

A. Unproductive sand, porosity 1.909 percent.

B. Reservoir sand, porosity 10.45 percent.

This mode of occurrence of the Medina gas makes the search for new fields in western New York more hazardous than in most naturalgas regions. As structure has not formed traps for the gas there is no surface guide to favorable sites for testing, and new fields are found by haphazard drilling. It would be helpful, however, when wells are sunk, to study the lithology of the gas-bearing zone by an examination of the drill cuttings and core samples of the sand, and to have electrical logs 11 made of the wells to obtain measurements of permeability and porosity. Such tests may indicate the directions of greatest porosity, in which the sand is more likely to contain gas.

11 Gillingham, W. J., Electrical logging in the Appalachian fields: Pennsylvania State College Bull Mineral Industries Experiment Station No. 21, pp. 30-52, 1937. 


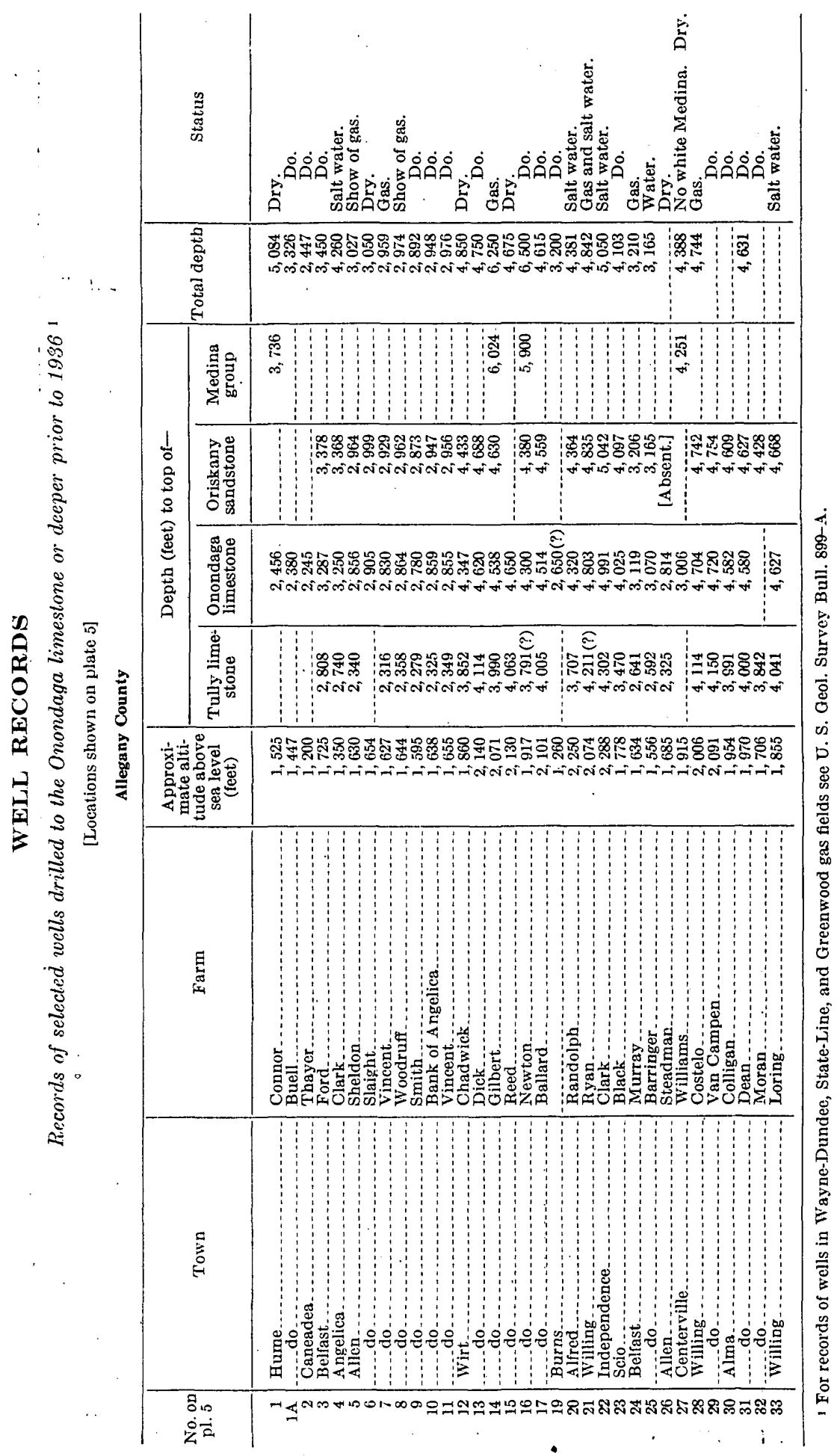









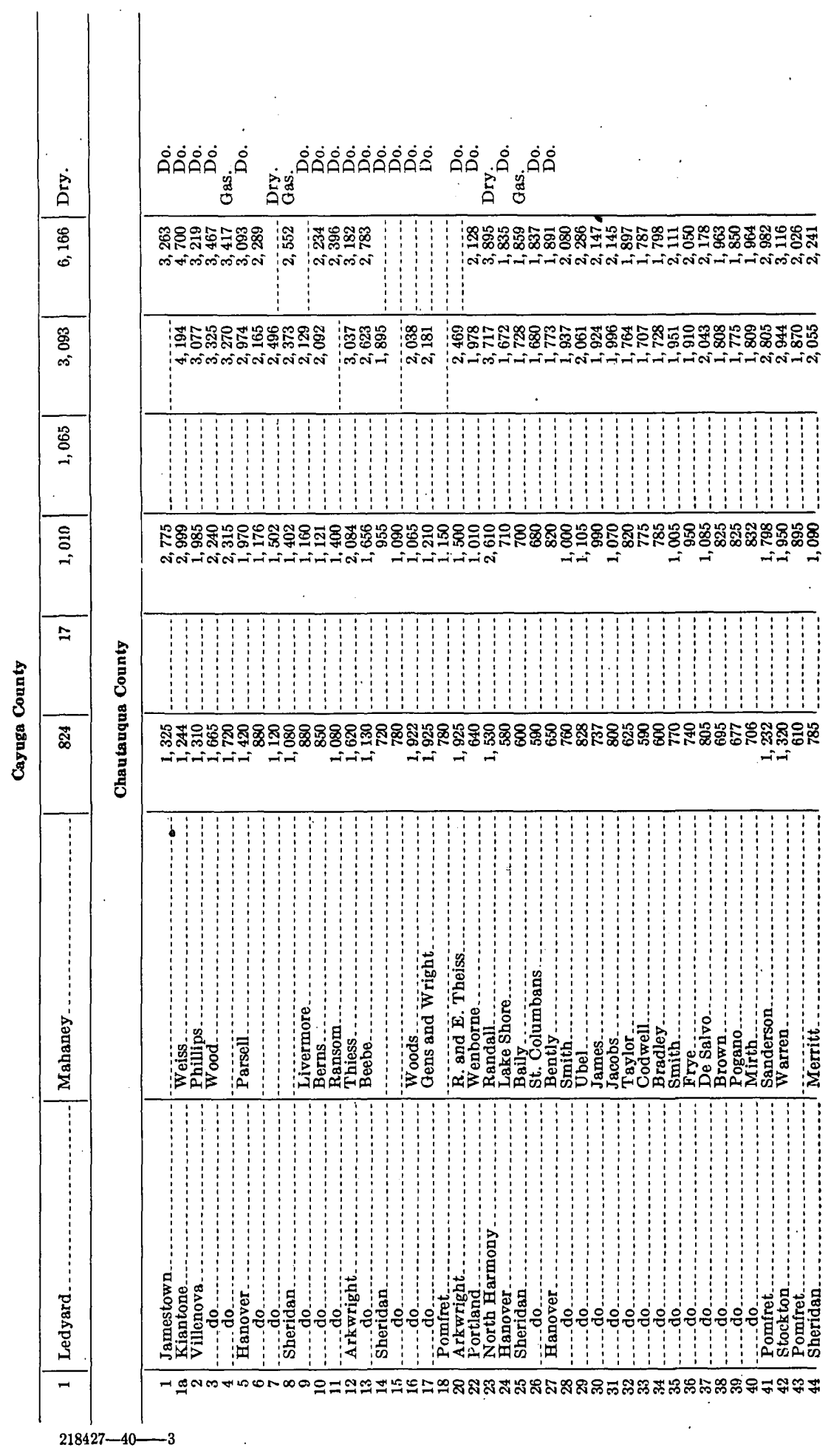












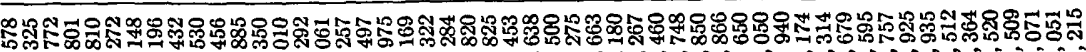



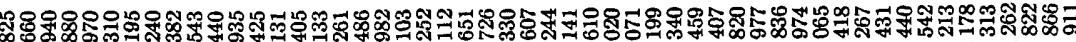

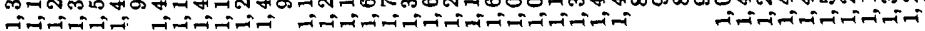

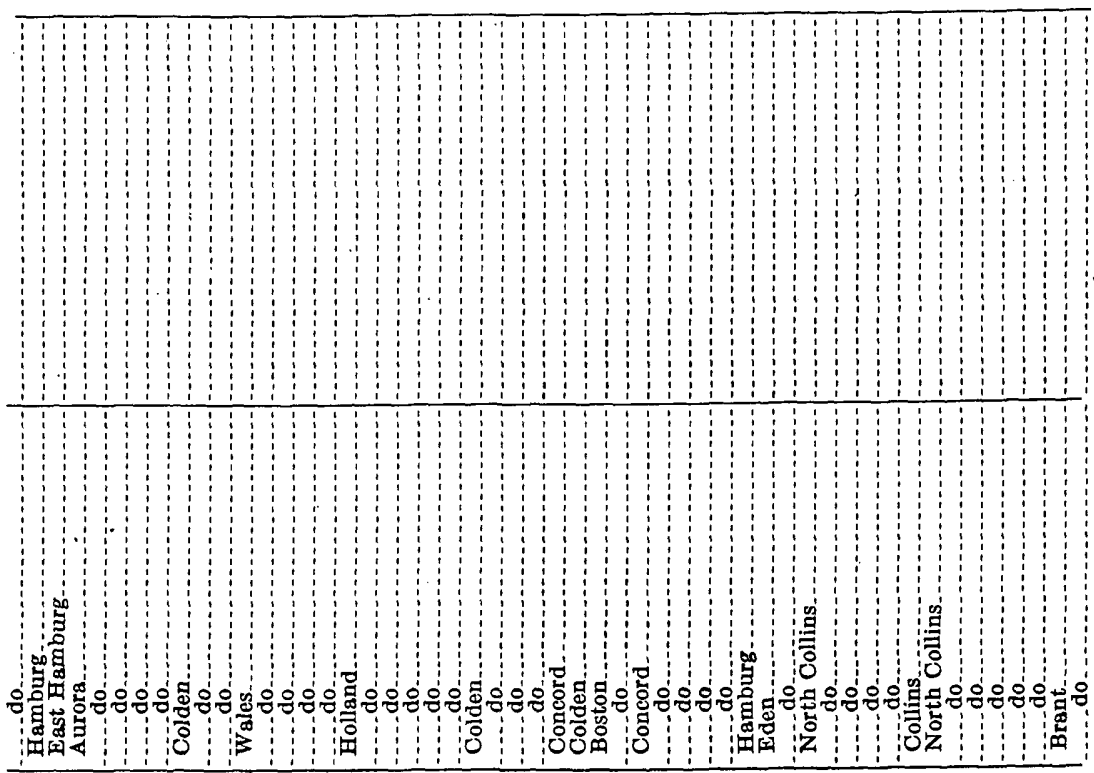

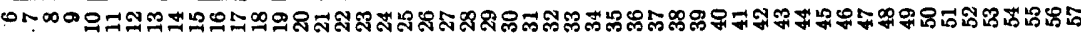




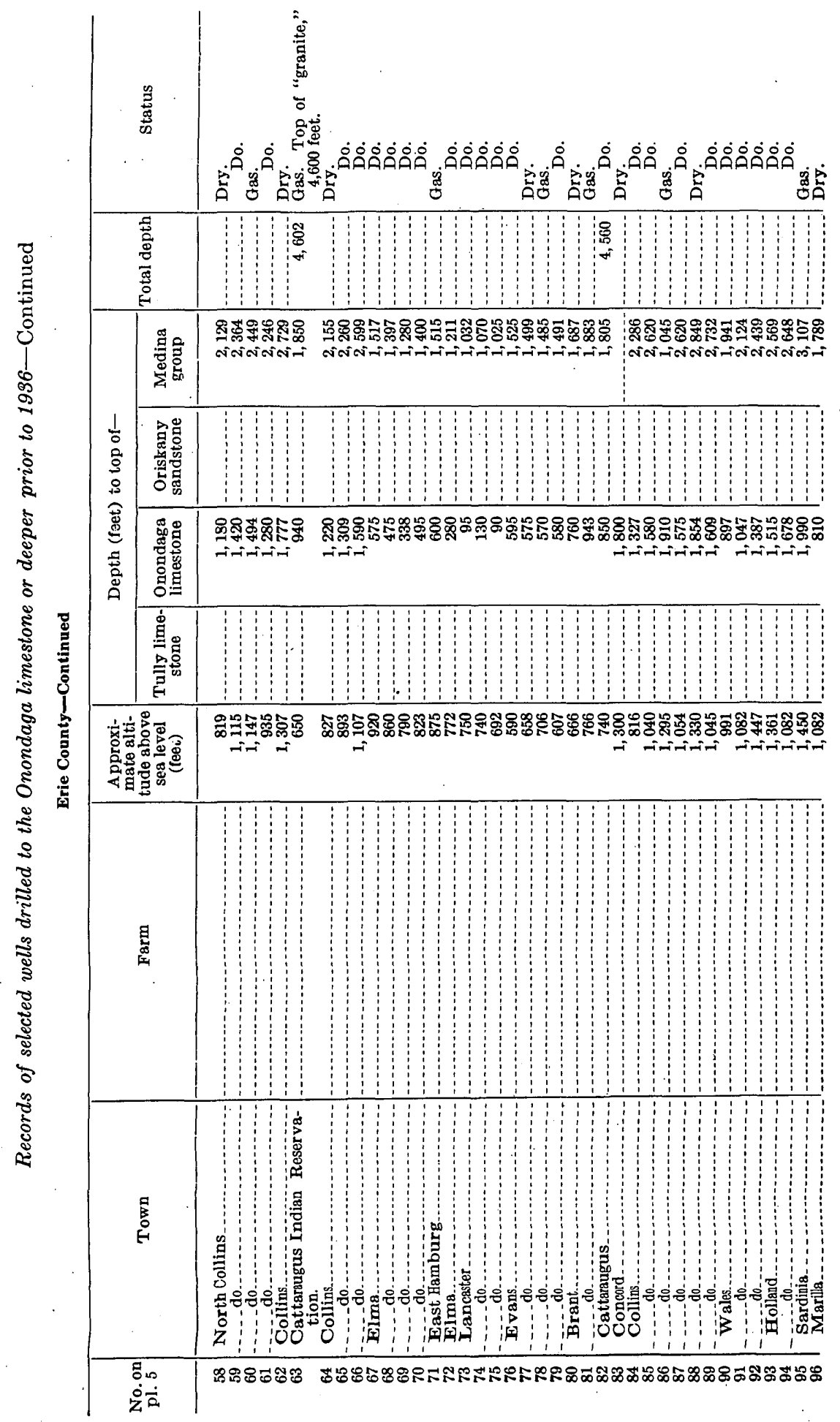




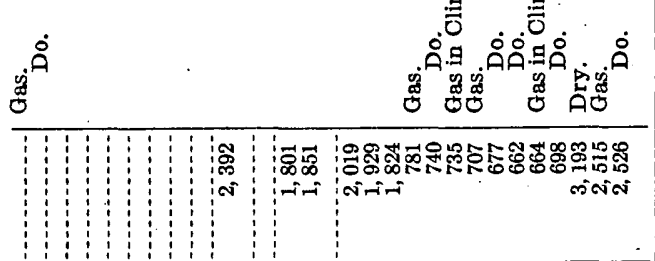

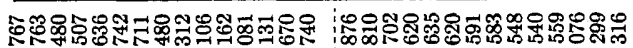

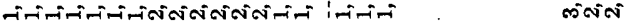

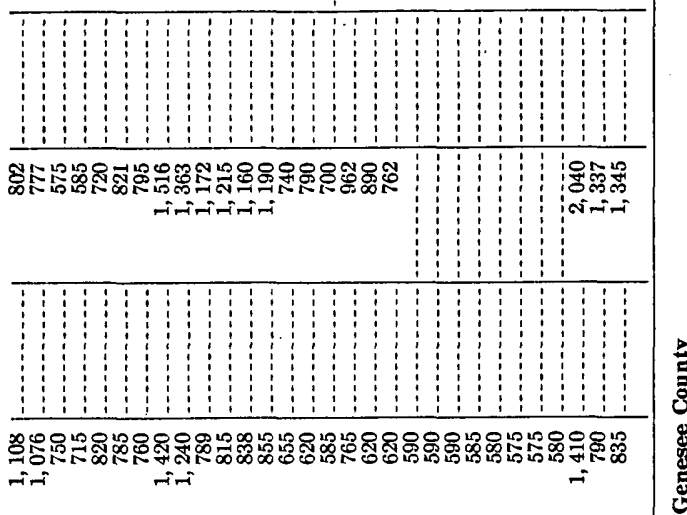



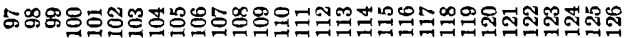

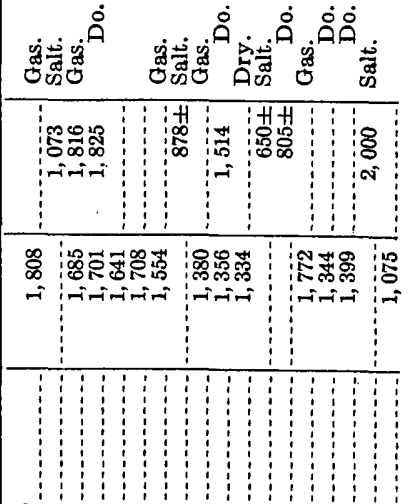

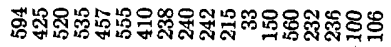



i inivinit $\rightarrow$

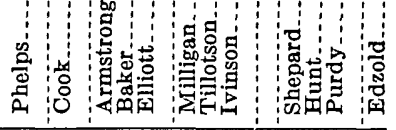

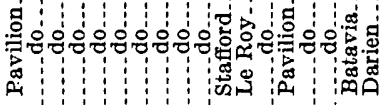

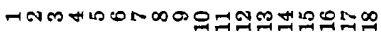



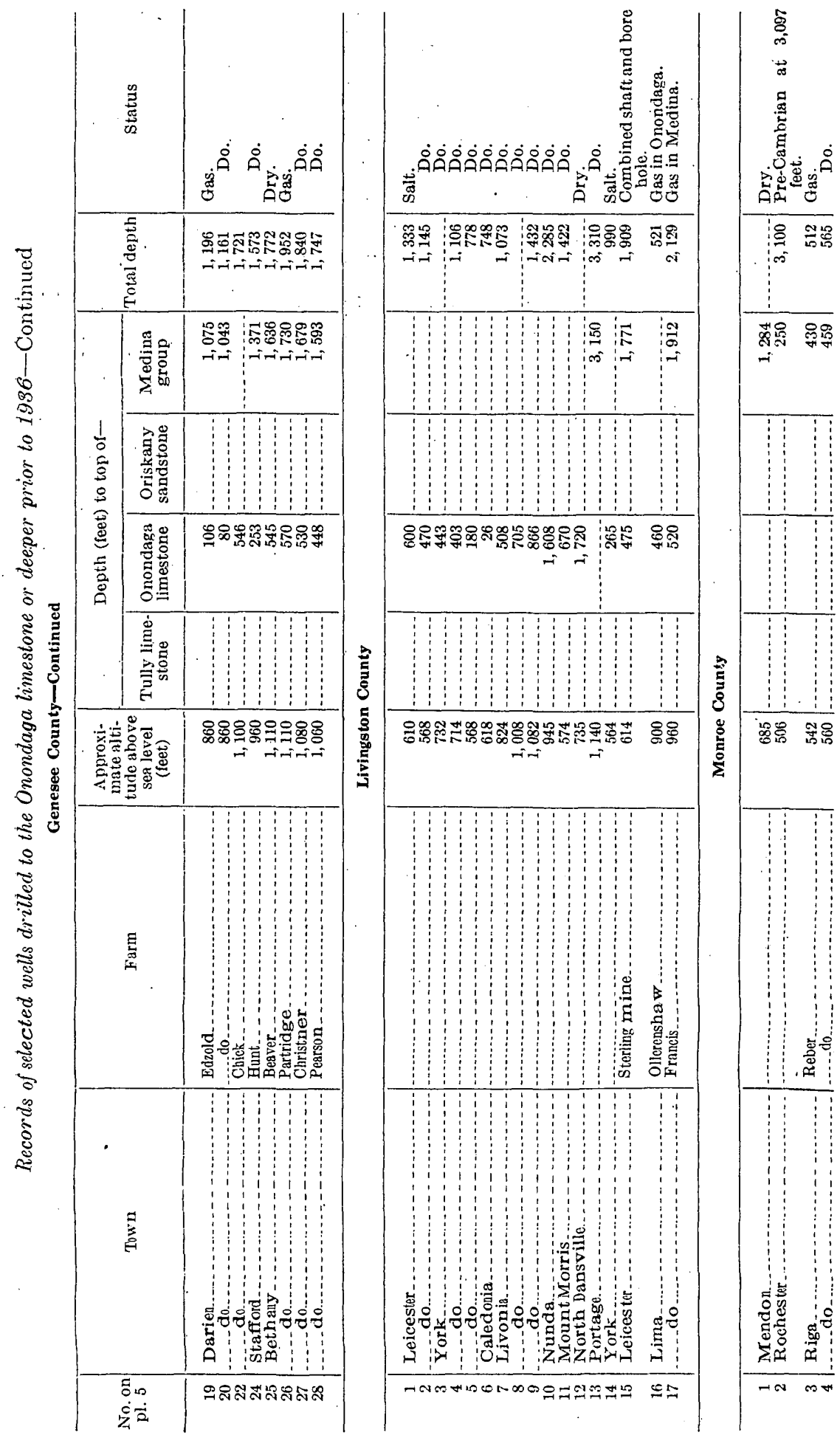


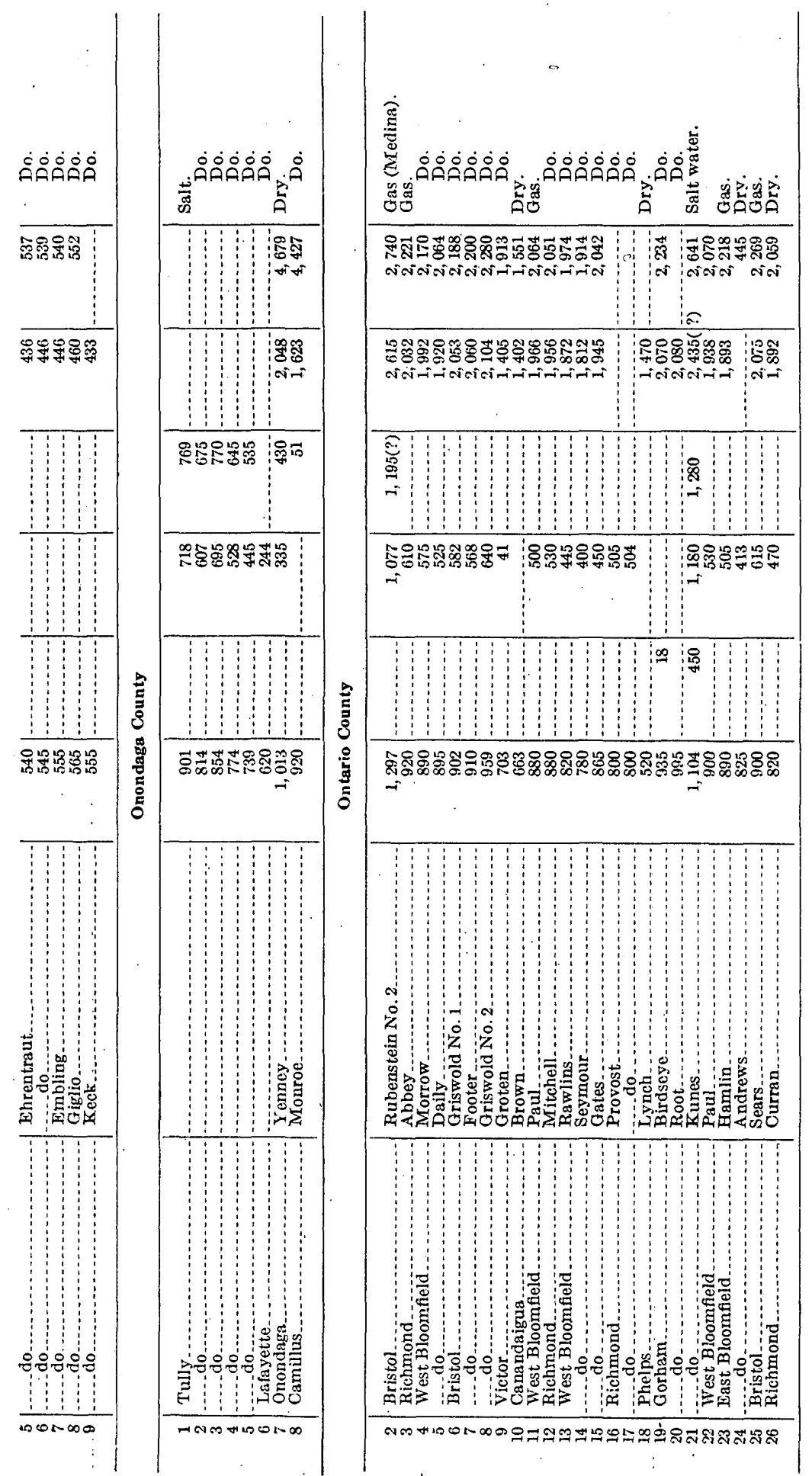


ర्ञ

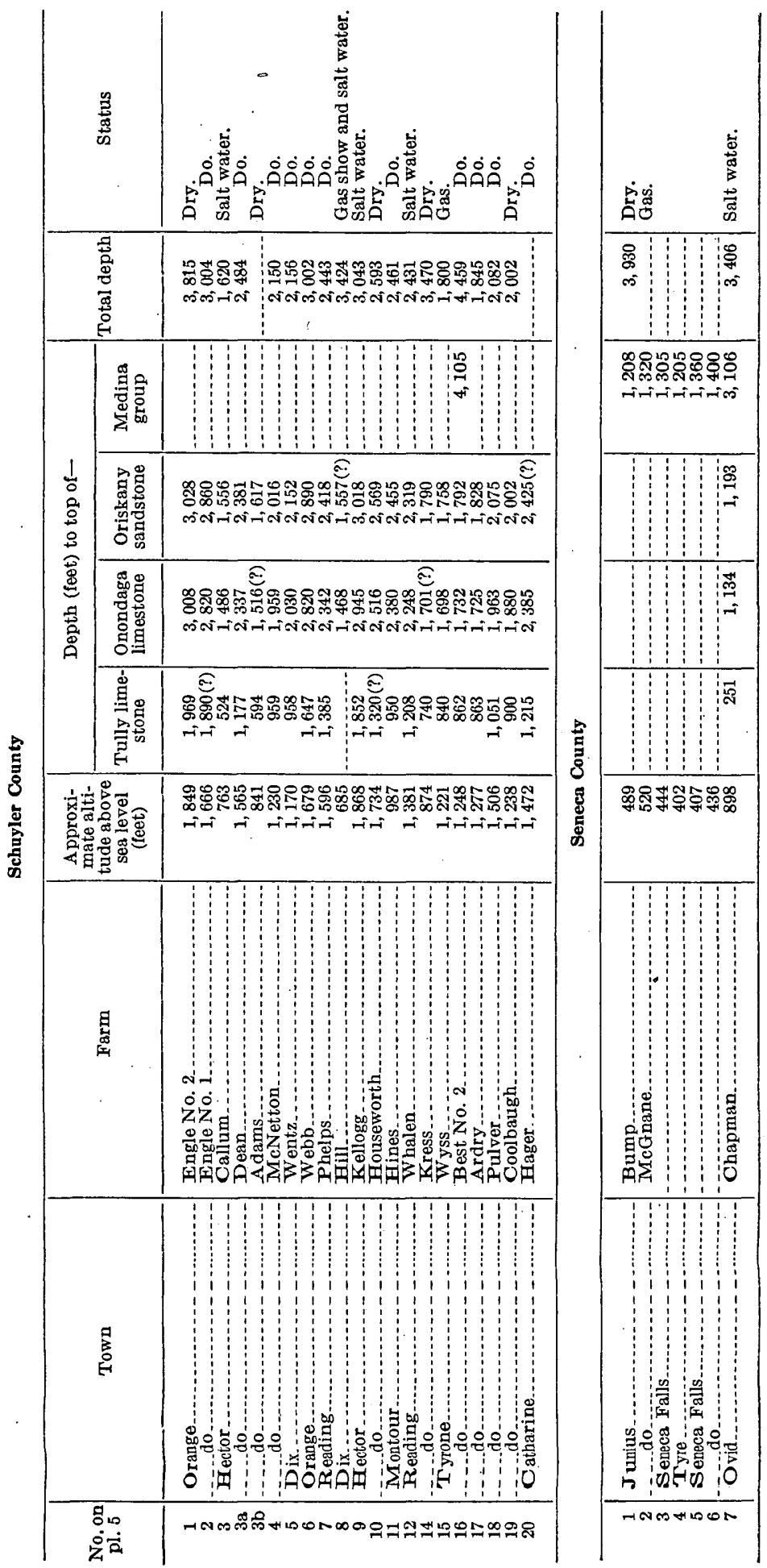









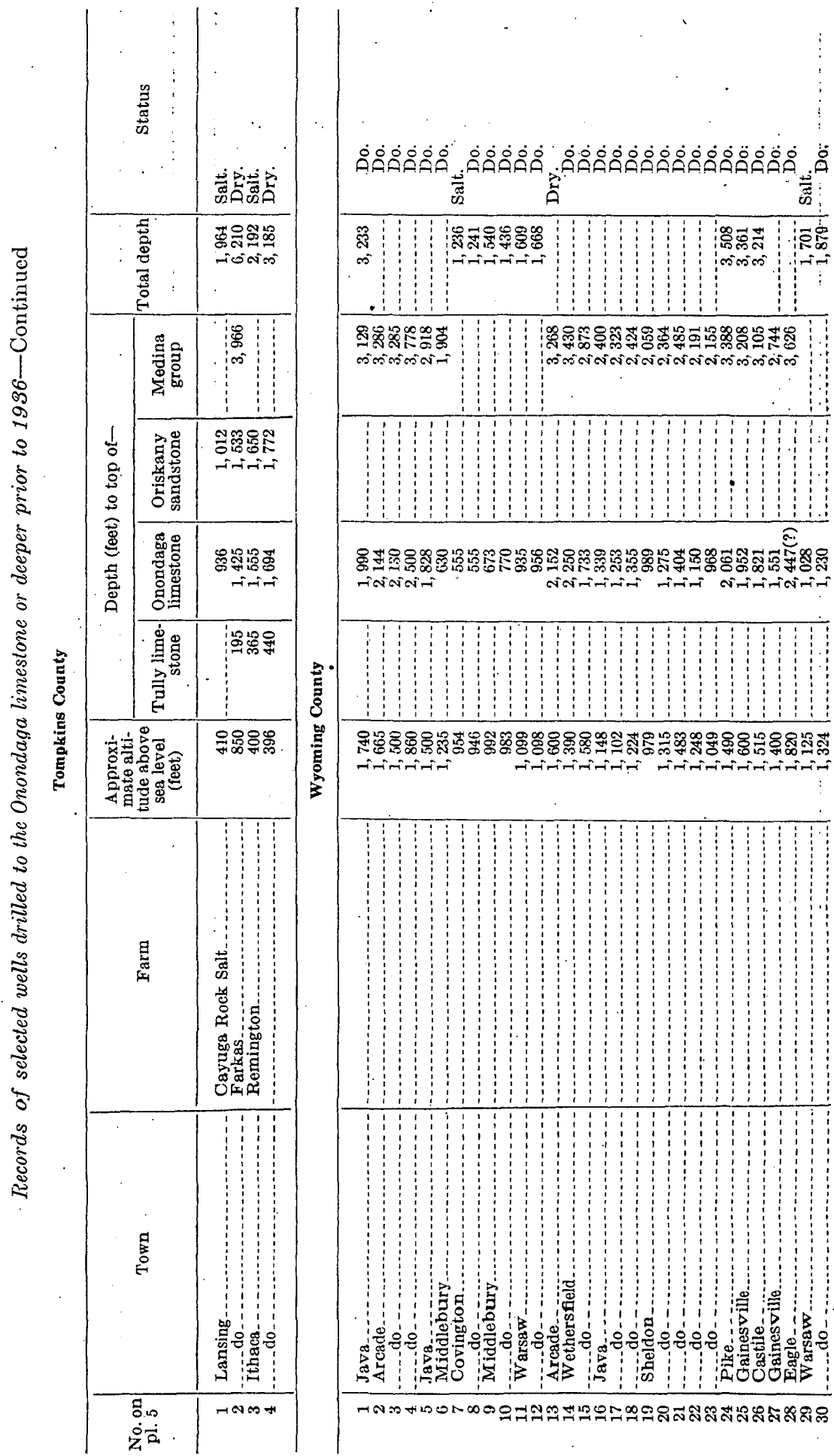



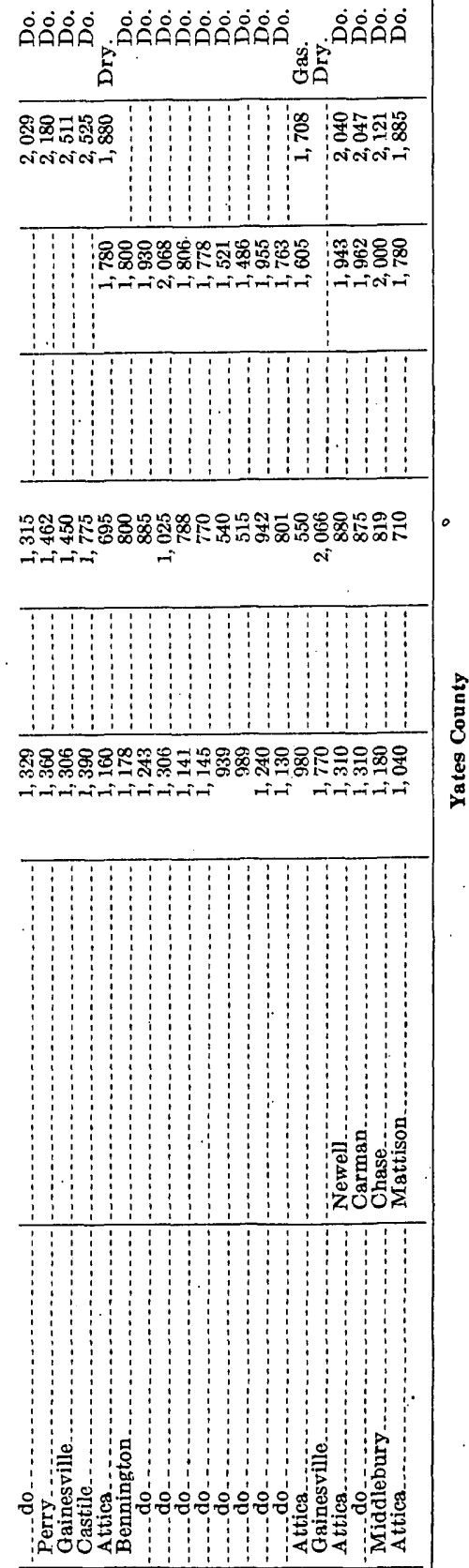

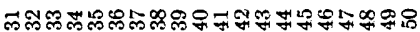

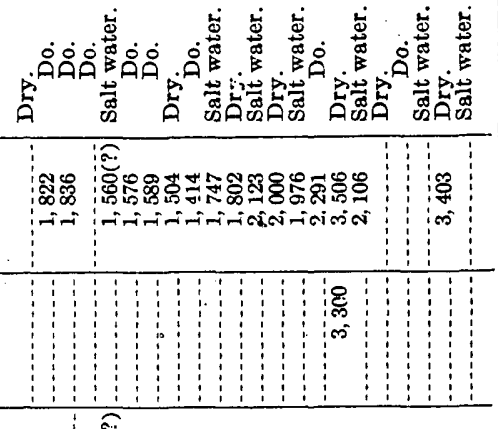

뭉

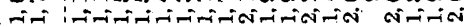

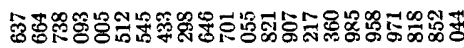



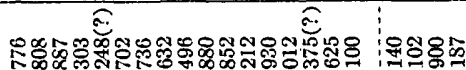
i- $-i-i=$

멱였

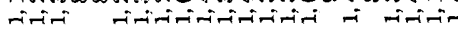

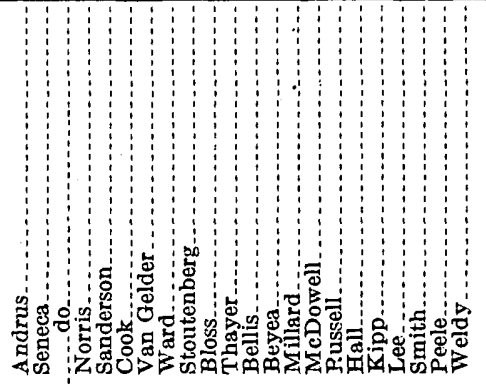

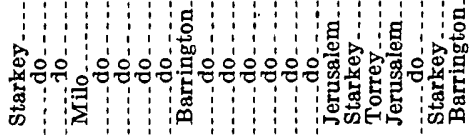

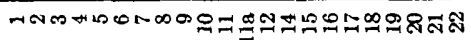





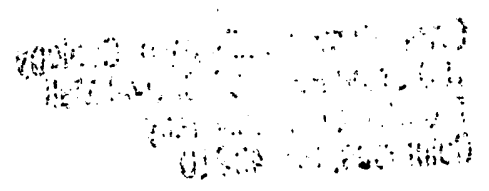

\section{INDEX}

\begin{abstract}
Acknowledgments for aid

Albion sandstone, character and distribution of

gas in.

sections of .

Allegany County, records of wells

Broome County, records of wells in.

Cattaraugus County, gas in records of wells in

Cayuga County, records of wells in

Chrutauqua County, gas in.
\end{abstract} records of wells in

Chemung County, records of wells in

Convergence of the strata

Cortland County, records of wells in..........

Cuylerville, section at....................... 76

Devonian rocks, gas in . . . . . .............

Dunkirk shale, convergence of Onondaga limestone and

Erie County, gas in. wells and dry holes in, location of. records of wells in

Federal Inmargency Administration of Public Works, allotwent of funds by....

Gas, occursence of $71,72,75,76,77$ relation of occurrence of, to lithology _... 75-78 relaticn of occurrence of, to structure 75 , pls. 7-8 Gas-producing areas, outline of

Genesee County, gas in. records of wells in

Gray band, age and thickness of

Key beds, convergence of ............... 73, pl. 6 features of

Lithology, relation of, to occurrence of gas... . 75-78

Livingston County, records of wells in....... section' in

Medina and Oriskany gas fields, structure of, comparison of

Medina group, age of 70,71 convergence of Onondaga limestone and. $73, \mathrm{pl} .6$ depth to. $79-91$ distribution of $75-76$

gas in $75-78$

key horizon for gas-bearing beds in ..... 72-73 Monroe County, records of wells in........... 86-87

Niagara gorge, section in
Page

Olean, thickness of rocks in vicinity of....... 73-74

Onondaga County, records of wells in....... 87

Onondaga limestone, character and distribution of.- 72

convergence of Dunkirk shale and........ 73 convergence of Medina group and ..... 73, pl. 6 convergence of Tully limestone and... . 73, pl. 6 depth to ........................ 74, 79-91

range in altitude of . . . . . . . . . . . . . . 74

Ontario County, records of wells in ......... 87

Ordovician rocks, gas in ...................... 75

Oriskany and Medina gas ficlds, structure of, comparison of .

Oriskany sandstone, character and distribution of ................ 52 , pl. 5

depth to .......

gas in... 72

Oswego sandstone, age of

Pre-Cambrian rocks, depth to .............. 73-74

Queenston shale, age of .................... 70,71

Red Medina sandstone, gas in.............. 77-78

Schuyler County, records of wells in......... 88

Seneca County, records of wells in............ 88

Silurian rocks, gas in . ............ 75

Sterling salt mine, section at................... $\quad 76$

Steuben County, records of wells in . ........ 89

Stratigraphy of the area . . . . . .

Structure, general features of ....... 74-75, pls. 7-8

relation of, to occurrence of gas..... 75, pls. 7-8

Structure in Medina and Oriskany gas flelds, comparison of ............... 75

Thorold sandstone, age and thickness of ..... 73

Tioga County, records of wells in............ 89

Tompkins County, records of wells in ........ $\quad 90$

Tully limestone, character and distribution of - 72 convergence of Onondaga limestone and. $73, \mathrm{pl} .6$



Wells, location of ................ pls. $5,7-8$ records of .............. 79-91

Whirlpool sandstone member, character of -. $\quad 77$ gas in................ 76, 77-78

White Medina sandstone member, character gas in

Wyoming County, gas in................. 75 records of wells in ................ 90-91

76 Yates County, records of wells in ........... 91 
Orton Remorial Library of Geology

180 Orton Hall, $155 \mathrm{~S}$. Oval Mall

The Ohio State Univerisity

Columbus, $\mathrm{OH} 43210$

wetn'

$\phi$

$x$ 